\title{
Learning Strategy and Cognitive Style: The Effect on Students' Writing Ability
}

\author{
T Tambi ${ }^{1}$, F Murtadho ${ }^{2}$, Z Rafli $^{3}$ \\ ${ }^{1,2,3}$ Universitas Negeri Jakarta, Jakarta, Indonesia \\ $\left\{{ }^{1}\right.$ tatatambi_lt15s ${ }^{3} @$ mahasiswa.unj.ac.id $\}$
}

\begin{abstract}
This paper investigates the effect of learning strategy and cognitive style on students' ability in writing Indonesian narrative writing text. It was conducted on the VII grade students at MTs Ibnu Taimiyah Bogor, West Java. This experimental study applies treatment by level design and two-factorial ANOVA analysis with $\alpha=0.05$. The sample was 80 students grouped into experiment and control classes. Writing test and GEFT instruments were used in collecting the data. The findings showed the students' ability in writing narrative text taught by inquiry-based communicative learning strategy was higher than those taught by expository-based communicative learning strategy.
\end{abstract}

Keywords: Inquiry-Based Communicative Learning Strategy, Expository-Based Communicative Learning Strategy, Writing Narrative Text, Cognitive Style

\section{INTRODUCTION}

In a learning process, considering teachers' experience in class, the principles of a teaching approach should not be rigid. The approach can or should be changed and adapt to the findings in class. A teaching approach is not a set of static and rigid principles which cannot be changed. As stated by Brown, an interaction between the approach and practice of teaching in class is a key to the creation of dynamic and spirited teaching [1]. A communicative approach, as stated by Kumaravadivelu, is an approach with authenticity, acceptability, and adaptability values [2]. In this study, a communicative approach was adapted with inquiry and expository teaching methods. According to Bruce Joyce and Marsha Wei, an inquiry teaching method is a method which makes students as the center of learning (child-centered learning) whereas in an expository method, teacher is the center of learning (teacher-centered learning) [3]. The adaptation of communicative approach with inquiry method is called an inquiry-based communicative language learning and the one with expository method is called an expositorybased communicative language learning.

The study of writing narration, currently, interes many researchers. A number of research report publication has been published in om journals. Fahey et al from the University of California, Irvine, examined the narative writing in digital form entitled Narrative Writing in Digital Formats: Interpreting the Impact of Audience. This experimental study, the type of writings of the subjects ar inspected when they write in online social media forums for their teachers and peers. Some aspects assessed are writing ability, mechanical errors, academic word 
use, and writing organization. One of the research findings is the research participants are more likely to write narrative texts when writing to peers [4].

One of the results of studies on communicative strategy was published in a journal by Giuseppina Scotto Di Carlo. In that study, Pathos was used as a communicative strategy in the dissemination of knowledge through online. Di Carlo described how the speaker the used Pathos technique in discussing, entertainment, and design to develop direct connection with the audience. The speaker tried to involve emotion during interaction with his audience. It was found that the success of direct discussion on technology, entertainment, and design through internet depended mostly on how the speaker was heard, remembered, and perceived as a trusted promoter of knowledge dissemination. However, there was another important thing namely how the speaker and technological device gave contribution to the audience. Scientific approach should be something shared by both professional elites and public, not something distanced and separated [5].

One's internal factors affect the success of his/her learning process and a cognitive style is an one of these internal factors. Herman A. Witkin was one of the pioneers of the theory of cognitive style and a learning style by using the field-dependency and field-independency concepts [6]. Compared to field-dependent learner type, learners with field-independent type are considered to be independent in developing their skills. In this study, the instrument developed by Othman, Raskin, and Witkin, known as a group embedded figures test (GEFT), was used as the instrument to develop the cognitive style. This instrument was used to measure students' ability to find a simple form hidden in a complex pattern. The test consisted of three parts containing 7 problems in the first part, 9 in the second part, and 9 in the third part. Through this test, students were grouped into field independent and field dependent cognitive style learners.

A study on the relation between cognitive style and writing ability titled A Study of Cognitive Style Effects on ESL Students' General Writing Ability was conducted by Faezeh Shojaei and Kedutso Kapfo. The objective of their study was to assess the effects of field independent and field dependent styles on the writing ability of ESL students. The subject of the study was 80 Iranian students studying at an international ESL class in Mysore City, India. Two groups of ESL students which were grouped based on GEFT were assigned to write an essay. Based on the results of a descriptive analysis and a t-test, it was revealed that cognitive style had significant effects on general writing ability of students of both field independent and field dependent cognitive style. It was shown that students with field independent cognitive style were superior to those with field dependent cognitive style [7].

Learning strategy becomes one of the issues in the teaching of writing naration unconsidering the learners' cognitive style. Teacher uses a single teaching strategy to students who have different cognitive styles when teaching narrative essays in the class. Therefore, it is necessary to improve teaching strategies in the teaching and learning process. The teaching strategies that fit with the cognitive style of students in orther that the learning objective is improved. In this study, the researcher conducted a study using inquiry-based communicative language learning strategies and expository-based communicative language learning strategies.

In this study, an inquiry-based communicative language learning strategy was implemented in experimental classes. Cognitive style of students was determined before the learning process started. The narrative writing ability of students with field independent cognitive style was expected to improve after they received narrative writing materials by using an inquiry-based communicative language learning strategy. Likewise, that of students with field dependent cognitive style was expected to improve after they received narrative writing materials by using an expository-based communicative language learning strategy. 
This research concerns in the writing skills of junior high school learners either grade 7, 8 , or 9. and equivalent taught both in grades VII, VIII, and IX. Writing naration is one of the subject tught continuslly for the three grsdes. The genre mapping of Indonesian language subject carried out based on the basic competencies of KI-3 and KI-4 of Junior High School Curriculum 2013, the narrative writing materials focus on narrative stories and local fables/legends for grade 7, drama narration for grade 8 , and inspiring story narratives for grade 9.

There was a different ability in narrative writing in Bahasa Indonesia between students studying using inquiry-based communicative language learning strategy and those studying using expository-based communicative language learning strategy. The hypothesis which stated that the ability to write a narrative writing in Bahasa Indonesia of students in the field independent cognitive style group is higher than that of students in the field dependent cognitive style group was accepted significantly. This was indicated by the higher mean score of the skill to write a narrative writing in Bahasa Indonesia of students having field independent cognitive style than that of students having field dependent cognitive style.

\section{RESEARCH METHOD}

An experimental method in a 2 × 2 factorial design was used. John W. Creswell stated that an experimental research is conducted to assess whether an idea (practice or procedure) affects the results or dependent variables. There are many and varied steps in conducting an experimental research. However, as stated by Creswell, there are several core steps as follows. First, the researcher should have an idea to be tested in the experiment. Second, the researcher selects individuals as the subject of the research (and share different experience to other individuals). Third, the researcher determine whether the subjects of the study experiencing the idea (practice or procedure) have better performance on certain parameter compared to those who do not have such experience [8].

A 2 x 2 factorial design was used and the layout of the experiment is shown in Table 1.

Table 1.: The Experimental Design

\begin{tabular}{ccc}
\hline & \multicolumn{2}{c}{ Learning Strategy (A) } \\
\cline { 2 - 3 } Cognitive Style $(\mathrm{B})$ & Inquiry-based & Expository-based \\
& Communicative Language & Communicative Language \\
Field Independent $\left(\mathrm{B}_{1}\right)$ & Learning Strategy $\left(\mathrm{A}_{1}\right)$ & $\mathrm{A}_{1} \mathrm{~B}_{1}$ \\
Field Dependent $\left(\mathrm{B}_{2}\right)$ & $\mathrm{A}_{1} \mathrm{~B}_{2}$ & $\mathrm{~A}_{2} \mathrm{~B}_{1}$ \\
Ability to Write a & Result of Narrative Writing & Result of Narrative Writing \\
Narrative Writing in & in Bahasa Indonesia & in Bahasa Indonesia \\
Bahasa Indonesia & & \\
\hline
\end{tabular}

Notes:

Dependent Variable: Ability to Write a Narrative Writing in Bahasa Indonesia

Treatment Variables:

A = Learning Strategy

A1 = Inquiry-based Communicative Learning Strategy

A2 = Expository-based Communicative Learning Strategy

Attribute Variables

$\mathrm{B}=$ Cognitive Style 
$\mathrm{B} 1=$ Field Independent Cognitive Style

B2 = Field Dependent Cognitive Style

$\mathrm{A}_{1} \mathrm{~B}_{1}=$ Students participating in learning process using an inquiry-based communicative strategy and having field independent cognitive style

$\mathrm{A}_{2} \mathrm{~B}_{1}=$ Students participating in learning process using an expository-based communicative strategy and having field independent cognitive style

$\mathrm{A}_{1} \mathrm{~B}_{2}=$ Students participating in learning process using an inquiry-based communicative strategy and field dependent cognitive style

$\mathrm{A}_{2} \mathrm{~B}_{2}=$ Students participating in learning process using an expository-based communicative strategy and field dependent cognitive style

The population in this study was all 180 students of Grade VII in odd semester, academic year of 2017/2018 in MTs Ibnu Taimiyah, Bogor. These students were divided into six learning groups, namely VII A, VII B, VII C, VII D, VII E, and VII F. All students had equal chance to be selected as samples in this study.

Samples were taken by using a cluster random sampling method. Wibisono stated that in a cluster random sampling method, all elements of a population share equal chance and are known to be selected as subjects. For example, if there are 1000 elements and the researcher needs to select 100 subjects, each element will have a 0.1 chance to be selected as subject. This sampling method is known as a simple random sampling which has the smallest bias and offers a good generalizability.

Four of six classes of Grade VII including VII A, VII B, VII D, and VII E in MTs Ibnu Taimiyah, Bogor were selected by using a drawing method. Then, another drawing was taken to select 2 classes as experiment and control classes. The drawing was conducted by using ballot paper. Each ballot paper was identified as either experiment or control class. Results of the drawing showed that classes VII A and VII D were selected as experiment classes and classes VII D and VII F as control classes.

Twenty of 59 students in the experiment class had a field independent cognitive style and 20 students had a field dependent cognitive style. Nineteen students were excluded from the subject of the study. These students followed a narrative writing in Bahasa Indonesia by using an inquiry-based communicative strategy. Twenty of 58 students in the control class had a field independent cognitive style and 20 students had a field dependent cognitive style. Eighteen students following a narrative writing in Bahasa Indonesia by using an expository-based communicative strategy were excluded from the subject of the study.

In grouping the students into field independent cognitive style and field dependent cognitive style in both experiment and control classes, 33\% of students of high score group and 33\% of students of low score group were selected. This was in line with what was stated by Dali S. Naga that subjects of the study could be divided into three parts which should not be equal in number. The top part was called the highest group and the bottom part, which was usually as big as the top part, was called the lowest group. No attention was given the middle part.

The experiment class was the one followed by students who became the samples of the study. These students were given a learning process by using an inquiry-based communicative language learning strategy in a narrative writing class by considering the students' field independent and field dependent cognitive styles. Meanwhile, students in the control class were sample students who followed a narrative writing learning process by using an expository-based communicative language learning strategy by considering the students' field independent and field dependent cognitive styles. 
The cognitive style of students in experiment and control classes was determined by using a general embedded figure tests (GEFT) developed by Raskin and Witkin in the form of pictures containing instructions to find the simple forms of complex pictures. Results of this test showed the style tendency the students had whether it was field independent or field dependent.

\section{RESULTS AND DISCUSSION}

Discussion was done on descriptive data of students' ability in narrative writing in Bahasa Indonesia and results of the hypothesis test described previously. The followings are the results of the test of the study hypothesis. There was a different ability in narrative writing in Bahasa Indonesia between students studying using inquiry-based communicative language learning strategy and those studying using expository-based communicative language learning strategy. This was shown by the results of two-way ANOVA test with Fcalculated (18.531) > Ftable (3.97) at significance level of $\alpha=0.05$.

This might be caused by the finding that inquiry-based communicative language learning strategy helped students fully develop their imagination in writing their narrative texts in Bahasa Indonesia. In general, students were found to have difficulty in developing their imagination which made it not easy for them to pour their ideas down in the a narrative form. Inquiry-based communicative language learning strategy helped students develop their own narrative ideas so that they needed to write independently. This had resulted in more varied narrative ideas and more interesting narrative organization.

In addition, in the inquiry-based communicative language learning strategy, students were led by their teacher to lead the students to find the intrinsic elements of narrative text, formulate the problems, develop hypothesis, and think to seek for information needed in hypothesis test, and draw conclusions independently by themselves.

In contrast, expository-based communicative language learning strategy was found to give students a lot of examples and guidance in the process of narrative text writing. Students received exercises and assignments in the process of narrative text writing. Teacher played a role as the center of the learning process. Based on the above explanation, students in the inquiry-based communicative language learning strategy group received higher scores than those in the expository-based communicative language learning strategy group.

Based on the above data, the following hypothesis test was conducted. There is a different ability of narrative writing in Bahasa Indonesia between students following a learning process through an inquiry-based communicative language learning strategy (A1) and students following a learning process through an expository-based communicative language learning strategy (A2). The tested statistical hypothesis was: $\mathrm{H} 0: \mu \mathrm{A} 1 \leq \mu \mathrm{A} 2$ and $\mathrm{H} 1: \mu \mathrm{A} 1>\mu \mathrm{A} 2$.

Results of two-way intercolumn analysis of variance showed that Fcalculated (18.531) was higher than Ftable (7.39) at a significant level of $\alpha=0.01$. This meant that $\mathrm{H} 0$ was rejected and H1 was accepted. Following this significant difference, the ability of students in these treatment groups was tested. It was found that the mean score of the ability to write a narrative text in Bahasa Indonesia of students in the inquiry-based communicative language learning group (A1) (86.60) was higher than that (73.85) of students of the expository-based communicative language learning group (A2). Therefore, students of the inquiry-based communicative language learning group had a better ability to write a narrative text than those of the expositorybased communicative language learning group. 


\section{CONCLUSIONS}

Based on the results of data analysis described previously, the following conclusion was drawn. The ability to write a narrative writing in Bahasa Indonesia of students following a learning process through an inquiry-based communicative language learning strategy was higher than that of students following a learning process through an expository-based communicative language learning strategy.

\section{REFERENCES}

[1] J. C. R. \& W. A. Renandya, Jack C. Richards \& R-Methodology in Language Teaching An Anthology of-2002.pdf. New York: Cambridge University Press, 2002.

[2] H. D. Brown, H. Douglas Brown_Teaching by Principles (Second Edition).pdf. San Francisco: Longman, 2000.

[3] and E. C. Bruce R. Joyce, Marsha Weil, Models of Teaching, Ninth. New York: Pearson, 2015.

[4] J. F. Lawrence, M. Niiya, and M. Warschauer, "Narrative Writing in Digital Formats: Interpreting the Impact of Audience," Psychol. Lang. Commun., vol. 19, no. 3, pp. 201221, 2015.

[5] G. S. Di Carlo, "Pathos as a communicative strategy for online knowledge dissemination: The case of TED talks," 3L Lang. Linguist. Lit., vol. 21, no. 1, pp. 23-34, 2015.

[6] H. Witkin, "Bipolar, one-dimensional models and measures." 2019.

[7] F. Shojaei and K. Kapfo, "A Study of Cognitive Styles Effect on ESL Students' General Writing Ability,” Int. J. Res., vol. 2, no. 9, pp. 94-99, 2015.

[8] J. W. Cresswell, Educational research : planning, conducting, and evaluating quantitative and qualitative research, Fourth. Boston: Pearson, 2012. 